\title{
INFLAMMATION OF THE SKIN \\ I. PHOSPHOLIPID METABOLISM IN SOME EXPERIMENTAL INFLAMMATIONS OF MOUSE SKIN
}

\author{
Hisashi TAKASU \\ Research Laboratory, Kobayashi Kose Co., Ltd. \\ Sakar-cho. Kita-ku, Tokyo, Japan
}

Accepted November 13, 1974

\begin{abstract}
Phospholipid metabolism in inflamed tissue of the mouse skin which had been induced by the application of 1-chloro-2, 4-dinitrobenzenc (DNCB), croton oil, or irradiation of uliraviolet rays was examined, and it was found that phospholipid levels had increased in the inflamed tissues. In the case of ultraviolet rays, the increase was temporary, and the level returned to that of control after 3 or 4 days. I1 the case of DNCB or croton oil, the level increased after a decrease for a short period. The pattern of the increase between physical and chemical irritation was different. Increase of incorporation of ${ }^{32} \mathrm{P}$ into phospholipid in inflamed tissue was examined, and it was observed that the level reached a maximum after one day. It is thus assumed that phospholipid plays an important role in the mechanism of inflammation.
\end{abstract}

Dasher and Hilliser, Bole et al., and Bole (1-3) suggested that phospholipid metabolism in the skin was transformed by inflammation, however, the role of phospholipid metabolism in inflammation is very complex. It has been well established that phospholipids play an important role in ion transport as one of cell membrane components. Normally, concentration of sodium ions in cells is lower than that in sero-fluids, as a result of the "sodium pump mechanism". This active transport moreover depends on ATPase which is activated by the phospholipids (4). There is a report (5) that corticosteroid inhibits the production of ATP in local skin inflammation, and it was of interest to study the role of phospholipid in the local skin inflammation. According to Spector's theory $(6,7)$, histamine, one of the most popular chemical mediators, is activated by an enzyme in the surface membrane of mast cells. Aizawa and Iwasaki (4) reported that phospholipid levels rose before an increase in weight of inflamed muscle tissues induced by implanation of cotton threads. Activity of ATPase contained in sarcolemma also increased.

In the present work, phospholipid level or the incorporation of ${ }^{32} \mathrm{P}$ into phospholipid was measured on inflamed tissues of mouse skin after application of 1-chloro-2, 4dinitrobenzene (DNCB), croton oil, or irradiation of ultraviolet rays.

\section{MATERIALS AND METHODS}

Male albino mice of dd strain weighing about $20 \mathrm{~g}$ were provided a commercial diet (CLEA Japan Inc., Tokyo) for 1 week before the experiment and were weighed daily. Five Part of this work was presented at the foth Congress of International Federation of Societies of Cosmetic Chemists, Barcelona, September, 1970. 
healthy animals were selected to form a group. All solvents used for extraction of phospholipids and proteins were reagent grade. A mercury lamp $(300 \mathrm{~W}$. Fuji Roentogen Inc., Tokyo) was constructed and adjusted so that the mice subjected to the rays could be placed as close as $T \mathrm{~cm}$ from the lamp.

Induction of experimental skin inflammation: Hair in an area of about $2 \times 2 \mathrm{~cm}^{2}$ on the back of a mouse was clipped as short as possible using an electric hair clipper 1 day before the experiment. Ultraviolet rays from a mercury lanp were irradiated on the mouse for $10 \mathrm{~min}$ from a distance of $7.0 \mathrm{~cm}$. A mouse was fixed and covered by a dark green sheet with an opening of $2 \times 2 \mathrm{~cm}^{2}$ over the clipped area. DNCB was dissolved in a mixture of chloroform and olive oil $(1: 1)$ to contain $0.1 \mathrm{~g} / \mathrm{ml}$. A solution of $0.05 \mathrm{ml}$ was dropped on the clipped area, and the solution was allowed to spread over the skin. After the chloroform had evaporated naturally, the olive oil was left on the skin as an adhesive of DNCB. Croton oil was dissolved in a mixture of ethanol and chloroform $(3: 1)$ to contain $0.25 \mathrm{~g} / \mathrm{ml}$, and $0.05 \mathrm{ml}$ of this solution was applied in a similar way. For the controls, the solvent without DNCB or croton oil was applied.

Extraction and defermination of phospholipid and protein: The mice were sacriliced on $6 \mathrm{hr}, 1,2,4,8$, and 12 days after the treatment respectively, and about $100 \mathrm{mg}$ of dorsal skin was removed. The skin was homogenized in $6 \mathrm{ml}$ of $5{ }^{\circ}$, cold trichloroacetic acid solution. The homogenized tissue was placed in a $15-\mathrm{ml}$ centrifuge tube and centrifuged (at $3000 \mathrm{rpm}$ ). The sediment was washed 3 times with $3 \mathrm{ml}$ each of cold trichloroacetic acid solution. Phospholipids were then extracted from the sediment with $3 \mathrm{ml}$ of $80^{\circ}$. ethanol and chloroform-ethanol $(1: 1)$, and twice with $3 \mathrm{ml}$ of ether. All extracts were combined and diluted with mixed solvent to $15 \mathrm{ml}$ in a volumetric flask. An aliquot of $2 \mathrm{ml}$ of this extract solution was pipetted into a borosilicate glass test tube and was evalporated to dryness with a stream of air below $60^{\circ} \mathrm{C}$. After $0.3 \mathrm{ml}$ of $70^{\circ} \%$ perchloric acid was added, the tube was heated until the liquid became clear. Inorganic phosphorus was determined by the method of Chen et al. (8). After the extraction of lipids, the residue was suspended in $3 \mathrm{ml}$ of $2 \%$ sodium hydroxide solution and heated in a boiling water bath for $5 \mathrm{~min}$. Proteins soluble in alkali were extracted, and this process was repeated twice. All the extracts were combined, diluted with water $1020 \mathrm{ml}$ in a volumetric flask, and 0.2 to $0.4 \mathrm{ml}$ of the extract solution was pipetted into a test tube. Protein was determined by the method of Lowry et al. (9).

Incuhation: After the dorsal skin was cleansed with ethanol, mice were sacrificed on $1,3,7$, and 12 days after the treatment respectively, and about $100 \mathrm{mg}$ of the skin was removed. The removed tissues were incubated at $37^{\circ} \mathrm{C}$ for $2 \mathrm{hr}$ in a stream of standard oxygen gas $\left(95^{\circ}, \mathrm{O}_{2} / 5^{\circ} " \mathrm{CO}_{2}\right)$. The incubation medium was Krebs-Ringer bicarbonate solution $(\mathrm{pH} 7.4)$ which conlained $0.1 \%$ of glucose and $50 / 2 \mathrm{Ci} / \mathrm{ml}$ of radioactive orthophosphate $\left(\mathrm{H}_{3}^{32} \mathrm{PO}_{4}\right)$. At the end of the incubation period, the tissue was washed twice with $5 \mathrm{ml}$ of cold isotonic sodium chloride solution. The phospholipids were extracted by the method mentioned above. Radioactivity in the phospholipid was determined (with $1.5 \mathrm{ml}$ of the extracts) hy Geiger-Müller counter. 


\section{RESULTS}

As shown in Table 1, inflammation induced by ultraviolet rays did not change the phospholipid level per wet weight of the tissue but increased its level per mg protein. The maximum level of the phospholipid per mg protein was observed at $6 \mathrm{hr}$ after the treatment in which the value showed $190 \%$ to the control, but this level began to decrease after 1 day. After 4 days, the level had returned to the control level. After 8 days, the phospholipid level reversed, became less than that of the control, and then began to return gradually. In contrast, the level of phospholipid per wet weight of tissue changed little.

TABLE 1. Effect of inflammation on the level of phospholipid in the skin

\begin{tabular}{|c|c|c|c|c|c|c|c|c|}
\hline \multirow{2}{*}{ Treatment } & \multirow{2}{*}{$\begin{array}{l}\text { Inorganic phosphorus } \\
\text { in phospholipid }(\mu \mathrm{g})\end{array}$} & \multicolumn{7}{|c|}{ Days after treatment } \\
\hline & & Control & 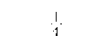 & 1 & 2 & 4 & 8 & 12 \\
\hline \multirow{2}{*}{ UV rays } & per $100 \mathrm{mg}$ wet lissue & $\begin{array}{l}37.2 \\
.1 .3\end{array}$ & $\begin{array}{r}40.7 \\
\div 1.2\end{array}$ & $\begin{array}{l}34.6 \\
=1.2\end{array}$ & $\begin{array}{r}38.8 \\
-1.3\end{array}$ & $\begin{array}{r}37.7 \\
+0.5\end{array}$ & $\begin{array}{r}38.5 \\
\pm 8.6\end{array}$ & $\begin{array}{r}37.9 \\
-2.0\end{array}$ \\
\hline & per mg protein & $\begin{array}{r}2.31 \\
-0.21\end{array}$ & $\begin{aligned} & 4.31 \\
= & 0.31\end{aligned}$ & $\begin{array}{r}3.42 \\
\therefore 0.09\end{array}$ & $\begin{array}{r}3.24 \\
+0.45\end{array}$ & $\begin{array}{r}2.45 \\
+0.27\end{array}$ & $\begin{array}{r}1.97 \\
\pm 0.18\end{array}$ & $\begin{array}{r}2.16 \\
\pm 0.36\end{array}$ \\
\hline \multirow{2}{*}{ DNCB } & per $100 \mathrm{mg}$ wet tissue & $\begin{array}{l}29.9 \\
0.4\end{array}$ & $\begin{array}{r}11.9 \\
-0.9\end{array}$ & $\begin{array}{r}24.5 \\
t=2.4\end{array}$ & $\begin{array}{r}30.9 \\
+0.7\end{array}$ & $\begin{array}{r}34.7 \\
\div \quad 1.4\end{array}$ & $\begin{array}{r}38.8 \\
-1.8\end{array}$ & $\begin{array}{l}31.6 \\
+1.7\end{array}$ \\
\hline & per mg protein & $\begin{array}{r}2.54 \\
+\quad 0.04\end{array}$ & $\begin{array}{r}2.17 \\
+0.06\end{array}$ & $\begin{array}{r}3.18 \\
\pm 0.24\end{array}$ & $\begin{array}{r}3.27 \\
\pm 0.12\end{array}$ & $\begin{aligned} & 3.04 \\
\therefore & 0.13\end{aligned}$ & $\begin{array}{r}3.01 \\
\pm 0.31\end{array}$ & $\begin{array}{r}3.30 \\
+\quad 0.21\end{array}$ \\
\hline \multirow{2}{*}{ Croton oil } & per $100 \mathrm{mg}$ wet tissue & $\begin{array}{r}33.5 \\
- \pm 1.0\end{array}$ & $\begin{array}{r}21.1 \\
\pm 0.7\end{array}$ & $\begin{array}{r}25.6 \\
+4.7\end{array}$ & $\begin{array}{r}35.7 \\
\pm 4.8\end{array}$ & $\begin{array}{r}35.9 \\
+2.8\end{array}$ & $\begin{array}{r}39.6 \\
+2.9\end{array}$ & $\begin{array}{r}39.8 \\
+4.1\end{array}$ \\
\hline & per ing protein & $\begin{array}{r}2.20 \\
+0.15\end{array}$ & $\begin{array}{r}2.20 \\
+0.22\end{array}$ & $\begin{array}{l}2.61 \\
0.23\end{array}$ & $\begin{array}{r}3.24 \\
+0.40\end{array}$ & $\begin{array}{r}2.96 \\
-0.11\end{array}$ & $\begin{array}{r}3.24 \\
+0.30\end{array}$ & $\begin{array}{r}3.95 \\
+0.18\end{array}$ \\
\hline
\end{tabular}

Values are means S.F.

On the other hand, inflammation induced by DNCB markedly decreased the phospholipid level per wet weight of tissue for a short period. The minimum level was $40 \%$ of the control. Inflammation by DNCB was different from that by ultraviolet rays in so far as the phospholipid level per mg protein decreased in the same as that per wet weight of tissue. After 1 day, both levels began to increase. An increase in phospholipid level per mg protein reached an earlier peak after 2 days, and the level was $130 \%$ of the control. The level per wet weight of tissue increased slowly and reached a maximum after 8 days. The maximum level was $130 \%$ of the control. In the case of inflammation by DNCB, restoration to the normal level required a longer period, and the level per mg protein was still $130 \%$ of the control after 12 days.

In the case of croton oil, decrease of phospholipid level per wet weight of tissue, as in the case of $D N C B$, was ohserved for a short period, but the decrease per mg protein was hardly observed. Increase of water in intlamed tissue was observed clearly for a short period. The increase of phospholipid then became more remarkable than that of water after 1 day, and increased gradually to $180 \%$ of the control after 12 days. Such an increase of phospholipid over a long period indicates different patterns of inflammation aceording to the inducing method. 
TABLE 2. Radioactivity of phospholipid in inflamed skin tissue

\begin{tabular}{|c|c|c|c|c|c|c|}
\hline \multirow[b]{2}{*}{ Treatment } & \multirow{2}{*}{$\mathrm{cpm}$} & \multicolumn{5}{|c|}{ Days after treatment } \\
\hline & & Control & 1 & 3 & 7 & $12^{-\cdots}$ \\
\hline \multirow{3}{*}{ UV rays } & per $\mu \mathrm{g}$ phosphorus & $251=36$ & $338 \pm 70$ & $313+62$ & $221 \div 50$ & $236 \div 28$ \\
\hline & per mg protein & $659 \div 48$ & $1128=59$ & $838 \therefore 63$ & $643=67$ & $670 \div 23$ \\
\hline & per $100 \mathrm{mg}$ wet tissue & $64=3$ & $124+26$ & $112: 14$ & $71-7$ & $80 \therefore 6$ \\
\hline \multirow{3}{*}{ DNCH } & per ug phosphorus & $360+46$ & $529 \pm 60$ & $298+40$ & $360=27$ & $378 \mid .19$ \\
\hline & per $\mathrm{mg}$ protein & $1771=89$ & $1937 \pm 123$ & $1859 \div 302$ & $2001 \div 101$ & $1029 \div 203$ \\
\hline & per $100 \mathrm{mg}$ wet tissue & $92 \star 1$ & $115:-9$ & $80 \cdot\ulcorner\quad 9$ & $93 \pm 8$ & $87-4$ \\
\hline
\end{tabular}

Values are means \pm S.E.

In order to determine synthetic patterns of phospholipid in inflamed skin tissues which varied by the method of induction, the tissues were incubated with radioactive inorganic phosphate (Table 2). In the case of ultraviolet rays, incorporation of ${ }^{32} \mathrm{P}$ into phospholipid was increased and its level was $160 \%$ of the control after 1 day. The level decreased for the following few days and then returned to the control level after 7 days. In the case of DNCB, an increase in the incorporation reached the maximum after 1 day, the same as in the case of ultraviolet rays, and returned to the control level after 7 days. In either case, an increase in the incorporation of ${ }^{32} \mathrm{P}$ was observed at an earlier period of inflammation, but the increase in incorporation was not always parallel to the increase in phospholipid level.

\section{DISCUSSION}

Although there are many methods of inducing inflammation, only a few can be applied to the skin. In the present work, two patterns in the increase of phospholipid level were observed following chemical irritation, DNCB or croton oil, and ultraviolet rays.

According 10 Matthews et al. (10), the level of phospholipids in the skin tissue is 0.7 to $0.8 \%$ of dry tissuc, but there are considerable differences in each tissue. Kopenhoefer (11) reported that the lipid phosphorus distribution in the skin of the steer is $0.0 \%$ in the hair, $0.031 \%$ in the basal epidermal region. Taylor et al. (12) found that in healing skin wounds of rats, the phospholipid included about $30 \%$ of total lipids in the stage of most rapid healing, as compared with approximately $3 \%$ in normal skin tissue. Bole et al. (2) reported that lipid or phospholipid level of inflamed tissue which had been induced by subcutaneous implantion of polyvinyl alchohol sponge was increased and sometimes decreased. Furthermore, Bole (3) reported that inflamed tissue which had been induced by the samo method was incubated with ${ }^{32} \mathrm{P}$-orthophosphate and ${ }^{14} \mathrm{C}$-glycerol, and the results showed a definite difference in the labeling patterns of ${ }^{32} \mathrm{P}$ and ${ }^{14} \mathrm{C}$. Aizawa and Iwasaki (4) reported that phospholipid metabolism rose before an increase in weight of inflamed nuscle tissue. Thus phospholipids together with ATPase appears to play an important role in the mechanism of inflammation. According to Johnson and Mier (13), the level of phoipholipid in the mouse skin was decreased by in vitro irradiation of ultri- 
violet rays, but the level of ${ }^{32} \mathrm{P}$ incorporated into phospholipid was increased by in rivo irradiation. They assumed that phospholipid decomposed by ultraviolet rays, but synthetic reaction of phospholipid in the skin was accelerated by the stimulative action of ultraviolet rays. It is still a matter of discussion whether this change is a primary chemical reaction or a reaction of inflammatory mechanism. According to the present data, phospholipid level increased not only by ultraviolet irradiation but also by DNCB or croton oil. In both cases, the amount of radioactive phosphorus incorporated into phospholipid from inorganic orthophosphate $\left(\mathrm{H}_{3}{ }^{32} \mathrm{PO}_{4}\right)$ was increased.

Thus, it may be assumed that, even if the phospholipid is decomposed with ultraviolet irradiation, inflammation accelerates the synthetic reaction of phospholipid in the skin tissue. If such is the case, then phospholipids do play an important role in the mechanism of inflammation. The increase of phospholipid level varied according to the method of indueing inflammation, and the result of ultraviolet irradiation was different from that after application of chemicals. The increase in the former case was temporary and the amount of radioactive phosphorus increased simultancously, but the phospholipid level per wet weight of tissue increased slightly. These facts indicate that the synthesis of phospholipid is increased by inflammation. It is known that phospholipids play an important role in cell membrane, one of these roles being the active transport of ions. Matsuyama (14) and Nohara (15) reported that inflammation decreased potassium ions and increased sodium, calcium, and magnesium ions in the skin tissue. Investigation is now underway to determine the relationship between phospholipid increase and the change in ion ratio.

Achnowledgement: The author wishes to thank Professor Y. Aizawa of the Department of Pharmacology, Tokyo College of Pharmacy, for his helpful advice.

\section{REFERENCES}

1) DAsher, W. ANi Hilliser, R.V.: J. Lab. clin. Med. 56, 760 (1960)

2) Bole, G.G., Rosman, S, AND LANDS, W.E.M.: J. Lab. dim. Hed. 59, 730 (1962)

3) Bolf, G.G.: I. clin. Invest. 42, 787 (1963)

4) AizaWA, Y. AND IWASAKI, M.: Yakugaku Zassi 89, 1664 (1969) (in Japanese)

5) Asoo, K., TANab, Y., Kato, T. and Takeuch, M.: Japan. J. Dermatol. 78, 993 (1968) (in Japanese)

6) SPector, W.G.: Pharmacol. Rev. 10, 475 (1958)

7) Spector, W.G.: Ant. N.Y. Acad. Sci. 116, 839 (1964)

8) Chen, P.S.J., Toribara, T.Y. and Warxer, H.: Analyt. Chem. 28, 1756 (1956)

9) Lowry, O.H., Roserbrougil, N.J. ANd Farr, A.L.: J. biol. Chem. 193, 265 (1951)

10) Matthews, V.J., NfwtoN, J.K. ANT Bloor, W.R.: J. biol. Chem, 188, 145 (1935)

11) Koppexhofftr, R.M.: J. biol. (hem. 116, 321 (1936)

12) Taylor, J.D., Pall, H.E. AnI) Paul, M.F.: Arch. Biochem. 17, 421 (1948)

13) Johnson, B.E. AXD Mubr, P.: Nature 194, 101 (1962)

14) Matsuyama, R.: Japan. J. Dermatol. 69, 1763 (1959) (in Japanese)

15) Nohara, N.: Japan. J. Dermatol. 68. 533 (1958) (in Japanese) 